\title{
PERSEPSI MASYARAKAT TERHADAP DAMPAK PERKEMBANGAN TAMAN WISATA ALAM KAWAH IJEN
}

\author{
Leily Suci Rahmatin \\ leily.suci.par@upnjatim.ac.id \\ Universitas Pembangunan Nasional "Veteran Jawa Timur
}

Received: January 30, 2021 | Accepted: February 19, 2021 | Published: May 1, 2021

Permalink/DOI: https://doi.org/10.53356/diparojs.v1i2.24

\begin{abstract}
ABSTRAK
Perkembangan wisata massal di TWA Kawah Ijen yang merupakan kawasan CA Kawah Ijen Merapi Ungup - Ungup menjadikan TWA Kawah Ijen rentan terhadap perubahan, baik dari segi fisik maupun sosial lingkungan masyarakat. Dampak yang ditimbulkan akan berpengaruh terhadap keberlanjutan TWA Kawah Ijen, penelitian ini dilakukan untuk melihat dampak yang ditimbulkan sehingga dapat meminimalisir dampak negatif. Metodologi penelitian yang digunakan dengan metode deskriptif kualitatif, pengumpulan data dilakukan melalui observasi, wawancara mendalam, FGD dan kuesioner sebagai data pendukung kuantitatif. Konsep analisis dalam penelitian ini yaitu dampak pengembangan pariwisata terhadap lingkungan fisik dan sosial, persepsi dan teori masyarakat tentang daur hidup kawasan pariwisata Butler. Dalam tahap perkembangannya TWA Kawah Ijen mengarah pada tahap development dengan kedatangan wisatawan massal, dampak yang ditimbulkan mempengaruhi daya dukung lingkungan baik fisik maupun sosial. Atraksi wisata utama berupa blue fire dan spot sunrise cenderung mengarah pada pemanfaatan kawasan terbatas dan dilindungi di TWA Kawah Ijen, sehingga perubahan fungsi lahan akan semakin meluas. Di sisi lain pariwisata juga memberikan dampak positif terhadap peningkatan pendapatan masyarakat, sehingga dalam perkembangan pariwisata di TWA Kawah Ijen akan menjadi wisata berkelanjutan jika masing - masing sector dan stakeholders berperan serta dan turut menjaga kelestarian baik aspek lingkungan maupun sumber daya sosial budaya masyarakat.
\end{abstract}

Kata Kunci: Taman Wisata Alam, Dampak Pariwisata, Persepsi Masyarakat

\begin{abstract}
The development of mass tourism in TWA Ijen Crater which is the CA area of Ijen Merapi Crater Ungup - Ungup makes TWA Ijen Crater vulnerable to changes, both physically and socially and in terms of the community environment. The impact will affect the sustainability of Ijen Crater TWA, this research was conducted to see the impact so as to minimize the negative impact. The research methodology used a descriptive qualitative method, data collection is observation, in-depth interviews, FGD and questionnaires as supporting quantitative data. The concept of analysis in this study is the impact of tourism development on the physical and social environment, community perceptions and theories about the life cycle of the Butler tourism area. In its development stage, Ijen Crater TWA leads to astage development with the arrival of mass tourists, the impact of which affects the carrying capacity of the environment both physically and socially. The main tourist attractions in the form of blue fire and sunrise
\end{abstract}


spots tend to lead to the use of limited and protected areas in Ijen Crater TWA, so that changes in land use will be more widespread. On the other hand, tourism also has a positive impact on increasing people's income, so that in the development of tourism in TWA Ijen Crater it will become sustainable tourism if each sector and stakeholders take part and participate in preserving both environmental aspects and socio-cultural resources of the community.

Keywords: Natural Tourism Park, Tourism Impact, Communit Perception

\section{PENDAHULUAN}

Perkembangan

pariwisata berkelanjutan harus dengan penetapan kebijakan pembangunan yang berorientasi pada daya dukung kesesuaian lingkungan, terutama pengendalian dampak pengembangan pariwisata yang memiliki lokasi di wilayah konservasi. Taman Wisata Alam (TWA) Kawah Ijen merupakan salah satu daya tarik wisata dengan kerentanan perubahan lingkungan fisik dan sosial, seperti perubahan kondisi lahan karena pembangunan maupun kondisi alam dan keberadaan desa penyangga sebagai pintu masuk kawasan wisata dengan sosial budaya masyarakaty yang masih kental. Lokasi wisata yang masuk dalam kawasan Cagar Alam (CA) Kawah Ijen Merapi Ungup - Ungup memerlukan kebijakan pelaksanaan pembangunan pariwisata yang berkelanjutan demi terjaganya ekosistem di sekitar TWA Kawah Ijen.

Konsep pariwisata dengan jenis ekowisata dan minat khusus sangat tepat diterapkan dalam perkembangan pariwisata TWA Kawah Ijen, akan tetapi target pendapatan dari penarikan retribusi tiket masuk dan retribusi lainnya menjadi tujuan utama dalam perkembangan TWA Kawah Ijen, tujuan dalam perolehan Pendapatan Negara Bukan Pajak (PNBP) seiring waktu merubah konsep pengembangan pariwisata TWA Kawah Ijen yang seharusnya jumlah wisatawan terbatas dan menyesuaikan daya dukung lingkungan menjadikan TWA Kawah Ijen sebagai pariwisata massal, serta tren wisata yang saat ini banyak bersinggungan dengan kegiatan alam dan berpetualang sebagai daya tarik wisata pilihan seperti blue fire di Puncak Kawah Ijen.

Analisis mengenai dampak dan persepsi masyarakat perlu dilakukan demi menjaga kelestarian ekosistem dan lingkungan sosial masyaakat sehingga menjadikan TWA Kawah Ijen sebagai daya tarik wisata yang berkelanjutan.

\section{KAJIAN PUSTAKA KONSEP DAN TEORI ANALISIS}

\subsection{Penelitian Terdahulu}

Referensi penelitian terdahulu yang dilakukan oleh Suryawardani dkk (2017) mengenai "A Structural Model of Foreign Tourists' Loyalty in Nature - based Tourism in Bali", menjelaskan bawah tren wisata saat ini mengarah pada kegiatan alam. Di Bali wisatawan dengan loyalitas berkunjung ke wisata alam mencapai 71 , $7 \%$, tingginya angka tersebut menunjukkan bahwa karakteristik dan sumber daya alam cukup banyak menarik minat wisatawan untuk berkunjung.

Penelitian lainnya dilakukan oleh Kusumastuti dan Adjie (2018) mengenai "Identifikasi Potensi dan Permasalahan Daya Dukung Lingkungan berdasarkan Aspek Daya Dukung Fisik, Daya Dukung Ekologis, dan Daya Dukung Sosial pada Pantai Baron, Kabupaten Gunungkidul, 
Yogyakarta”, ketahanan lingkungan akan menjadi rentan ketika jumlah kunjungan meningkat, tidak hanya dari aspek lingkungan fisik melainkan dari segi sosial masyarakat yang tidak seimbang dalam menghadapi perubahan yang terjadi dalam waktu singkat. Tingginya jumlah kunjungan tidak hanya sebagai pendukung pendapatan secara ekonomi melainkan juga berdampak pada aspek lingkungan lainnya.

Tulisan lainnya dari Wijaya dan Kanca (2017) yang berjudul "Dampak Pembangunan Pariwisata dalam Pengembangan Pariwisata Provinsi Bali", dampak pembangunan pariwisata tidak hanya disebabkan oleh satu faktor, negatif atau positif dampak yang terjadi merujuk pada rencana pembangunan. Pelibatan dan keseimbangan dalam pengendalian dampak dari masing - masing aspek pariwisata akan menjadikan kegiatan tersebut berkelanjutan.

Penelitian mengenai kawasan TWA Kawah Ijen ditulis oleh Widowati dan Nadra (2017) mengenai "Evaluasi Penerapan Prinsip - Prinsip dan Kriteria Ekowisata di Kawasan TWA Kawah Ijen Banyuwangi”, menjelaskan penerapan prinsip ekowisata sangat tepat dilaksanakan di daya tarik wisata tersebut dikarenakan lingkungan yang mendukung dan konsep pengembangan yang mengarah pada ekowisata. Namun kriteria yang lebih dominan di TWA Kawah Ijen tidak dijelaskan secara terperinci. Selanjutnya penelitian mengenai siklus hidup destinasi wisata kritik mengenai konsep siklus hidup pantai sebagai tempat liburan, dengan judul "Exploring the Tourist Destination as a Mosaic: The Alternative Life Cycles of the Seaside Amusement Arcade Sector in Britain" oleh Chapman (2016). Siklus hidup sebuah destinasi tidak hanya terjadi sesuai rentan waktu yang diinginkan dengan tahapan yang sudah ada. Siklus hidup sebuah daerah tujuan wisata akan dipengaruhi cepat lambatnya pembangunan, perubahan dalam perkembangan pariwisata dipengaruhi oleh banyak indikator dan tidak berdiri secara homogen.

\subsection{Taman Wisata Alam}

Dalam Undang - Undang No 5 tahun 1990 tentang Sumber Daya Alam Hayati dan Ekosistemnya, mengartikan bahwa TWA merupakan kawasan konservasi yang dapat dimanfaatkan dalam kegiatan rekreasi dengan mengedepankan ketentuan konservasi di setiap kegiatan rekreasi.

\subsection{Persepsi}

Persepsi dianggap cara seorang individu memilih, mengatur, dan menginterpretasikan informasi yang masuk untuk menciptakan gambaran mengenai situasi dan kondisi yang sedang terjadi. Persepsi tidak hanya pada rangsangan fisik, juga termasuk hubungan stimulus dengan bidang di sekitarnya dan kondisi individu itu sendiri. Kata kuncinya adalah individu dapat memiliki persepsi yang berbeda dari keberatan dan situasi yang sama (Kotler, 2002).

\subsection{Dampak Pariwisata terhadap Lingkungan Fisik}

Implikasi pariwisata terhadap lingkungan terbagi atas berbagai komponen yang dipengaruhi, perkembangan pariwisata yang tidak terkendali berdampak negatif terhadap keberlanjutan daerah tujuan wisata, 
terutama dari daya dukung lingkungan dan keseimbangan alam.

Menurut Richardson dan Fluker 2004 (dalam Pitana, 2009), dampak pariwisata terhadap lingkungan:

1. Implikasi penggunaan alat transportasi, sebagai sumber polusi suara (kebisingan), polusi gas hasil buangan kendaraan bermotor dan penggunaan energi fosil dunia terbesar.

2. Dampak pembangunan fasilitas pariwisata, perkembangan pariwisata berdampak terhadap kerusakan, masalah pada daerah perbukitan dan pegunungan, selain berkurangnya luas hutan juga menyebabkan erosi dan longsor. Pencemaran langsung yang diakibatkan oleh pembuangan limbah restoran atau rumah makan serta sarana pendukung pariwisata lainnya seperti toilet umum.

3. Dampak lainnya pengoperasian pariwisata, dapat memberikan tekanan pada lingkungan melalui berbagai cara yaitu:

a. Tekanan terhadap sumber daya alam terutama ketika kegiatan atau atraksi wisata bersinggungan langsung dengan alam.

b. Perusakan habitat kehidupan liar yang ditimbulkan dari beberapa aktivitas selama kegiatan pariwisata yang menghilangkan beberapa fungsi alam.

\subsection{Dampak Pariwisata terhadap Sosial Ekonomi}

Implikasi atau dampak sosial diartikan sebagai perubahan yang terjadi pada sosial masyarakat akibat kedatangan wisatawan Pizam and Milman (1984) mengklasifikasikan dampak sosial pariwisata yaitu:
1. Dampak terhadap aspek demografi (jumlah penduduk, umur, perubahan piramida penduduk).

2. Dampak terhadap mata pencaharian (perubahan pekerjaan dan distribusi pekerjaan). (dalam Pitana, 2009)

Menurut Cohen 1984 (dalam Pitana, 2009) dampak pariwisata terhadap kondisi sosial ekonomi masyarakat lokal yaitu: dampak terhadap pendapatan masyarakat, dampak terhadap kesempatan kerja, dampak terhadap harga - harga, dampak terhadap kepemilikan dan kontrol.

\subsection{Tourism Area Life Cycle Model}

Teori Tourism Area Life Cycle (TALC) atau siklus hidup destinasi oleh Butler 2006. Butler menyatakan daerah wisata akan mengalami siklus yang terbagi dalam empat bagian yaitu Discovery, Local Control, Institutionalism, dan Stagnation, Rejuvenation or Decline. Keempat bagian ini akan dialami oleh sebuah area wisata sejalan dengan berlalunya waktu, empat tahapan tersebut memiliki karakteristik dengan perubahan dari segi perkembangan sarana prasarana, ekonomi hingga promosi.

\section{METODE PENELITIAN}

Penelitian dilakukan di TWA Kawah Ijen yang berada di dua wilayah administrasi kabupaten yakni Banyuwangi dan Bondowoso. Pemilihan lokasi penelitian di TWA Kawah Ijen dikarenakan perkembangan pariwisata yang dilakukan dengan konsep ekowisata, akan tetapi saat ini mulai bergeser massal. Letak lokasi penelitian yang berada di dua wilayah administrasi yang berbeda juga memberikan tantangan tersendiri, terutama regulasi perencanaan 
pengembangan yang diperlukan. Regulasi dari Balai Konservasi Sumber Daya Alam (BKSDA) yang menaungi TWA Kawah Ijen, juga kerjasama antara Banyuwangi Bondowoso serta masyarakat terkait di dua desa penyangga.

Fokus penelitian terbatas pada bagaimana persepsi masyarakat mengenai perkembangan TWA Kawah Ijen terhadap dampak lingkungan fisik dan sosial yang mendukung keberadaan pariwisata di TWA. Teknik pengumpulan data dilakukan dengan melakukan pengamatan terlibat di TWA Kawah Ijen. Wawancara mendalam dengan menentukan informan pangkal yaitu Kepala Resort Konservasi Wilayah 18 Kawah Ijen, untuk menemukan key informan yaitu kepala Seksi Wilayah V BKSDA, Kepala Bidang Wilayah III BKSDA dan koordinator masing - masing unit usaha wisata, wawancara mendalam juga dilakukan dengan pemerhati lingkungan dan ekowisata. Penggunaan kuesioner untuk mendukung data kualitatif dengan melibatkan 100 responden dari masyarakat lokal yang masuk dalam unit usaha jasa wisata. Pelaksanaan FGD selama 90 menit yang dilaksanakan dengan anggota diskusi dari pihak akademisi, lima koordinator unit usaha jasa wisata di TWA Kawah Ijen, pihak BKSDA, dan Dinas Pariwisata dari Kabupaten Banyuwangi dan Kabupaten Bondowoso.

\section{HASIL DAN PEMBAHASAN}

\subsection{Gambaran Umum}

TWA Kawah Ijen berada di kawasan CA Kawah Ijen Merapi Ungup - Ungup, ditetapkan sebagai TWA dengan luas 92 ha sesuai dengan Surat Keputusan Menteri Pertanian No. 1017/Kpts-II/Um/12/1981 pada tanggal 10 Desember 1981. Luas TWA 3,59\% dari total keseluruhan CA Kawah Ijen Merapi Ungup - Ungup yakti seluas 2.560 ha. TWA Kawah Ijen secara geografis berbatasan langsung dengan Kawasan CA Kawah Ijen Merapi Ungup Ungup, jalan lintas Kabupaten Bondowoso dan Banyuwangi, lereng Merapi dan aliran sungai Banyulinu, secara administrasi wilayah terletak di dua kabupaten yakni Kabupaten Bondowoso dan Kabupaten Banyuwangi.

Geografi wilayah dan demografi masyarakat lokal yang berpengaruh atau dipengaruhi oleh TWA Kawah Ijen, sebagai CA maupun daya tarik wisata terutama adalah keberadaan masyarakat yang tinggal di Kabupaten Banyuwangi dan Kabupaten Bondowoso Daerah pemukiman masyarakat lokal yang langsung berbatasan dengan CA maupun TWA Kawah Ijen merupakan desa penyangga yang terdapat di Kecamatan Licin bagian Timur yang masuk wilayah Kabupaten Banyuwangi yang merupakan wilayah penyangga dan sekaligus pintu masuk dari wilayah bagian Timur. Kecamatan Ijen di bagian Barat yang masuk wilayah Kabupaten Bondowoso yang merupakan wilayah penyangga dan sekaligus pintu masuk dari wilayah bagian Barat TWA Kawah Ijen.

\subsection{Aspek Kesesuain Lahan}

Penataan Blok TWA Kawah Ijen merujuk pada zonasi penataan blok sesuai dengan Surat Keputusan Direktur Jenderal Perlindungan Hutan dan Pelestarian Alam dan Rencana Pengelolaan Taman Wisata Alam Kawah Ijen periode 2001 - 2025. Rancangan penataan blok TWA Kawah Ijen dibagi menjadi dua yaitu blok perlindungan seluas 68,15 ha $(74 \%)$ dan blok pemanfaatan seluas 23,85 ha. Blok 
pemanfaatan terbagi atas pemanfaatan umum dan pemanfaatan terbatas. Pembagian blok berdasarkan SK Dirjen PHKA terbagi menjadi:

a. Blok perlindungan seluas 68,15 ha, terbagi atas Areal Kawah Ijen seluas 44,371 Ha dan Paltuding 23,779 ha.

b. Blok pemanfaatan seluas 21,793 ha, Merupakan kawasan yang diperuntukkan bagi kegiatan wisata alam dengan kegiatan khusus atau tertentu, termasuk fasilitas pendukungnya. Blok pemanfaatan TWA Kawah Ijen terbagi atas tiga area yaitu area Paltuding di luar blok perlindungan dengan luas 19,501 ha, area Paltuding menuju Pondok Bunder seluas 1,357 ha merupakan jalan setapak, Pondok Bunder dengan luas

0,068 ha, Pondok Bunder menuju area bibir Kawah Ijen merupakan jalan setapat seluas 0,867 ha dan bangunan yang diperbolehkan hanya berupa shelter.

c. Blok pemanfaatan terbatas seluas 2,057 ha. Kegiatan yang dapat dilakukan pada blok pemanfaatan terbatas yaitu usaha pemanfaatan belerang secara tradisional (sublimasi).

Perkembangan pariwisata harus memperhatikan jumlah kunjungan dengan kesesuaian lahan, TWA Kawah Ijen sebagai kawasan konservasi dalam perkembangan pariwisata perlu mempertimbangkan kelestarian ekosistem, sehingga pembatasan kunjungan ketika kegiatan pariwisata berkembang sangat diperlukan. Berdasarkan perencanaan pengembangan TWA Kawah Ijen asumsi dalam pembatasan kunjungan, dengan panjang jalur pendakian dari Paltuding menuju bibir kawah sepanjang $3.200 \mathrm{~m}$ dengan lama perjalanan 2,5 jam dan jarak antar orang berjalan $\pm 10 \mathrm{~m}$, secara sederhana Daya Dukung Lingkungan (DDL) dapat dihitung sebagai berikut:

DDL $=$ Panjang Jalan Setapak $\times$ orang/hari Jarak Orang Berjalan

$\mathrm{DDL}=3200 \mathrm{~m} \times 1$ orang/hari $10 \mathrm{~m}$

DDL $=320$ orang/hari

(Sumber: Perencanaan Jangka Panjang TWA Kawah Ijen)

Pengunjung TWA Kawah Ijen terdiri atas wisatawan dan penambang belerang, jika setiap hari terdapat 150 orang penambang belerang, dan kawasan TWA Kawah Ijen dibuka untuk kegiatan wisata antara pukul 04:00 am hingga 12:00 am maka daya dukung lingkungan TWA Kawah Ijen terhadap pengunjung sebesar,

a. DDL Terendah $=(320-150)$ orang/hari

$$
=170 \text { orang } / \text { hari }
$$

b. DDL Tertinggi $=\left\{\left(\begin{array}{lll}2 & \mathrm{x} & 320\end{array}\right)-150\right\}$ orang/hari

$$
=490 \text { orang/hari }
$$

(Sumber: Perencanaan Jangka Panjang TWA Kawah Ijen)

Berdasarkan perhitungan DDL untuk kegiatan di bibir kawah paling lama 30 menit atau ekuivalen dengan 11 orang/ 30 menit saat kunjungan terendah dan 31 orang/ 30 menit saat kunjungan tertinggi. Sehingga perkembangan TWA Kawah Ijen lebih tepat ketika mengusung konsep wisata minat khusus dan pariwisata berkelanjutan.

\subsection{Aspek Masyarakat Penyangga}

Masyarakat yang bermukim di kawasan penyangga TWA Kawah Ijen sebagian besar terbagi atas dua wilayah administrasi Kabupaten Banyuwangi dan 
Kabupaten Bondowoso, kedua daerah tersebut dipengaruhi secara spasial maupun sektoral dengan dikembangkannya TWA Kawah Ijen. Partisipasi masyarakat dan usaha meminimalisir pertentangan dalam perkembangan pariwisata, akan menjamin berkurangnya masalah sosial yang akan terjadi dengan adanya pariwisata di TWA Kawah Ijen. Upaya penyuluhan, pembinaan dan perencanaan yang terus melibatkan masyarakat, menjadi modal utama dalam menanggulangi dampak sosial yang nantinya akan timbul dengan adanya pariwisata. Keberadaan pariwisata diharapkan dapat memberikan peluang kerja yang lebih luas di lingkungan masyarakat, terutama dari pengadaan dan perkembangan sarana prasarana dan usaha pariwisata di TWA Kawah Ijen.

\subsection{Perkembangan Taman Wisata Alam Kawah Ijen}

Perkembangan pariwisata dilihat dari perubahan di berbagai aspek menjadikan daerah pariwisata mengalami siklus kehidupan, proses dari penemuan bahkan penuaan yang juga mengalami masa sehat dan sakit, ketika proses perubahan tidak berjalan dengan baik atau cenderung merusak. Upaya destinasi pariwisata dalam melalui periode perubahan tentunya juga ditentukan berdasarkan penciptaan kegiatan baik sebelum kegiatan pariwisata berkembang maupun selama pariwisata menjadi sektor yang memberikan nilai manfaat.

Kerentanan terhadap perubahan siklus hidup akan semakin cepat terjadi, karena pada dasarnya kegiatan pariwisata sangat sensitif terhadap keberadaan tempat yang dikunjungi, keberadaan pariwisata di TWA Kawah Ijen mengalami siklus perubahan dalam waktu yang cukup singkat, peningkatan jumlah sarana dan pembatasan jumlah kunjungan yang tidak berhasil menjadikan destinasi wisata ini berada dalam tahap development. Tahapan yang dianggap tidak terlalu menjadi masalah atau kekhawatiran dalam proses perkembangan sebuah daerah tujuan wisata, tahapan saat pariwisata masih menjadi prioritas dalam upaya peningkatan nilai ekonomi.

Tahap perkembangan mencerminkan penciptaan pemasaran yang baik atas suatu destinasi wisata, perkembangan TWA Kawah Ijen memiliki prioritas pemasaran dengan branding blue fire fenomena alam yang terjadi tidak di semua gunung berapi yang memiliki sumber tambang belerang. Pengaruh dan kerjasama dengan pihak swasta dilakukan, demi meningkatkan kuantitas dan kualitas sarana penunjang pariwisata, menciptakan daya tarik wisata baru dan memberikan peluang bagi pihak swasta, untuk ikut serta dalam penanaman modal dan penyediaan akomodasi. Pihak swasta yang juga terlibat dalam kegiatan TWA Kawah Ijen PT Candi Ngrimbi sebagai koordinasi pemasaran kegiatan penambangan belerang, yang juga menarik minat bagi wisatawan yang datang untuk melihat proses penambangan tradisional. PT Sura Parama Setia memiliki hak dalam perkembangan sarana pendukung pariwisata, yang pada mulanya dalam pengadaan dan pembangunan kereta gantung kemudian beralih pada penyediaan jasa akomodasi, yang hingga saat ini masih menjadi pertimbangan dikarenakan lokasi yang masih dalam blok perlindungan dan pemanfaatan terbatas.

Keberhasilan pemasaran dari branding blue fire juga akan berdampak 
pada kesiapan daerah tujuan wisata untuk menghadapi over capacity pada jumlah kunjungan, hal ini akan mempercepat laju perubahan dalam siklus hidup sebuah daerah tujuan wisata.

Ketika tahap development berlangsung, ada beberapa aspek yang harus menjadi pertimbangan terutama ketika berkaitan dengan perubahan kontrol pembangunan dan alih fungsi lahan. Pembangunan saran toilet dan tiang pemancar di bagian puncak TWA Kawah Ijen, pembangunan tandon air di sepanjang pendakian serta adanya pelebaran jalan pendakian, akan memengaruhi fungsi dan ketahanan kawasan terutama ketika terjadi iklim dengan intensitas hujan yang tinggi.

Perubahan dalam fisik terlihat dalam waktu empat tahun terakhir, pembangunan sarana penunjang pengelolaan dari semi permanen menjadi permanen. Pada lain hal, ketika tahap development berlangsung tenaga kerja di luar penduduk lokal akan sangat diperlukan sebagai bentuk perbaikan dari SDM yang kurang memadai, tingkat pendidikan dan pengetahuan yang menjadi poin utama dalam pengambilan tenaga di luar penduduk lokal. Akan tetapi penetapan yang kurang pertimbangan akan memberikan kecemburuan sosial, hal ini akan berdampak pada keberlangsungan hubungan antara sektor pariwisata, baik pengelola maupun pemilik usaha wisata.

\subsection{Dampak Lingkungan Fisik}

Perkembangan pariwisata yang cukup cepat mengalami perubahan memberikan tekanan terhadap lingkungan dan ekologikal sebuah daya tarik wisata, TWA Kawah Ijen yang sebagian besar produk pariwisata mengandalkan kawasan lindung serta berpotensi menimbulkan dampak lingkungan akan menjadi perhatian khusus ketika tekanan pada kawasan konservasi terus meningkat.

Tantangan terbesar yang dihadapi dalam kebijakan perkembangan lingkungan dan pengelolaan pariwisata di TWA Kawah Ijen berupa pengadaan sarana prasarana pendukung pariwisata. Perubahan fungsi kawasan dan blok pemanfaatan akan menimbulkan dampak, terutama ketika timbul kebijakan mengenai keberadaan dan pemenuhan transportasi modern dengan sifat massal.

Tingginya jumlah kunjungan wisatawan yang hanya terfokus pada dua atraksi wisata utama di TWA Kawah Ijen, merubah arah kebijakan dalam perluasan blok pemanfaatan sebagai daerah wisata menjadi pilihan. Problem kunjungan musiman wisatawan juga menjadi permasalahan dalam meminimalisir dampak lingkungaan baik penggunaan transportasi maupun sarana prasarana lainnya. Pendapat responden mengenai dampak perkembangan pariwisata, sebagian besar menyatakan bahwa pariwisata memberikan dampak negatif terhadap lingkungan sebagaimana yang ada pada tabel 4.1 mengenai dampak pariwisata terhdap lingkungan.

Tabel 4.1

Persepsi Masyarakat mengenai Dampak Pariwisata terhadap Lingkungan

\begin{tabular}{|c|c|c|c|c|c|}
\hline & & $\begin{array}{c}\text { Frequen } \\
\text { cy }\end{array}$ & Percent & $\begin{array}{c}\text { Valid } \\
\text { Percent }\end{array}$ & $\begin{array}{c}\text { Cumulative } \\
\text { Percent }\end{array}$ \\
\hline \multirow[t]{4}{*}{ Valid } & 1 & 14 & 14,0 & 14,0 & 14,0 \\
\hline & 2 & 72 & 72,0 & 72,0 & 86,0 \\
\hline & 4 & 14 & 14,0 & 14,0 & 100,0 \\
\hline & $\begin{array}{l}\text { Tot } \\
\text { al }\end{array}$ & 100 & 100,0 & 100,0 & \\
\hline
\end{tabular}

Sumber: Data Sekunder diolah, 2020

Tabel 4.1 mengenai pendapat responden yang merupakan masyarakat 
lokal berpendapat bahwa pariwisata memberikan dampak buruk terhadap lingkungan dengan persentase mencapai $72 \%$ dari 100 responden namun ada sebagian yang menyatakan pariwisata berdampak baik terhadap lingkungan karena dengan adanya pariwisata setiap ekosistem yang terbentuk akan terpelihara dengan baik.

Kerusakan dan masalah ekosistem yang ditimbulkan berupa sedimentasi juga terjadi dalam pembangunan sarana penunjang di TWA Kawah Ijen area puncak. Intensitas angin dengan membawa sebagian material gas belerang menimbulkan kerusakan pada bangunan, selain itu letak bangunan yang berada di tebing dengan kemiringan tanah menghambat jalur air dan menimbulkan sedimentasi di sisi lain tanah yang tidak mengalami pembangunan, erosi dan longsor mungkin terjadi saat puncak musim hujan. Perubahan fungsi guna lahan di area puncak berupa bangunan shelter, toilet dan tiang pemancar, perubahan lainnya yaitu pembangunan toilet dan tandon air di sepanjang jalur pendakian dari Paltuding hingga Pondok Bunder yang pada mulanya merincikan bahwa di sepanjang jalur pendakian hanya shelter yang bisa dibangun dan pembangunan pagar pembatas di lokasi berbahaya sebagai pelindung bagi wisatawan. Hal demikian juga tampak terlihat ketika beberapa bagian jalan di semen, penambahan pagar permanen di sisi tebing sebagai pengamanan pendakian, pelebaran jalan pendakian menyebabkan longsoran kecil di sisi jalan pendakian.

Perubahan fungsi lahan juga dirasakan oleh masyarakat lokal yang turut andil dalam pelaksanaan pariwisata di TWA Kawah Ijen, 53\% responden menyatakan pariwisata sebagai penyumbang terbesar dalam alih fungsi lahan, sebagaimana pendapat responden pada tabel 4.2 mengenai dampak pariwisata terhadap perubahan fungsi lahan.

Tabel 4.2

Persepsi Masyarakat mengenai Dampak Pariwisata terhadap Alih Fungsi Lahan

\begin{tabular}{llrrr}
\hline & $\begin{array}{c}\text { Frequenc } \\
y\end{array}$ & Percent & $\begin{array}{c}\text { Valid } \\
\text { Percent }\end{array}$ & $\begin{array}{c}\text { Cumulative } \\
\text { Percent }\end{array}$ \\
\hline Valid 1 & 6 & 6,0 & 6,0 & 6,0 \\
& 53 & 53,0 & 53,0 & 59,0 \\
2 & 10 & 10,0 & 10,0 & 69,0 \\
3 & 26 & 26,0 & 26,0 & 95,0 \\
4 & 5 & 5,0 & 5,0 & 100,0 \\
5 & 100 & 100,0 & 100,0 & \\
Total &
\end{tabular}

Sumber: Data Sekunder diolah, 2020

Masyarakat berpendapat bahwa perubahan yang terjadi akibat pariwisata dalam perubahan fungsi lahan cukup berdampak buruk, namun $26 \%$ menyatakan pariwisata baik terhadap fungsi lahan karena batas blok perlindungan akan terlihat dan keberadaan fasilitas lainnya mendukung perkembangan daerah sekitar.

Perkembangan pariwisata TWA Kawah Ijen juga mengakibatkan pencemaran langsung dari pembuangan limbah restoran, buangan limbah toilet yang hingga saat ini belum memiliki kebijakan tetap sehingga menyebabkan polusi tanah dan udara. Permasalahan lainnya akibat limbah buangan berkaitan dengan limbah logam, plastik, cair dan beberapa limbah bungkus makanan yang sebagian besar tidak dapat terurai secara alami, dan munculnya vandalisme serta pelanggaran larangan batas kunjungan juga menjadi tantangan dalam pengoperasian pariwisata di TWA Kawah Ijen

Tekanan yang sering dihadapi TWA 
Kawah Ijen terhadap sumber daya alam lebih sering diakibatkan oleh atraksi wisata yang bersinggungan langsung dengan alam, tracking menuju puncak Kawah Ijen, maupun menuju bibir kawah untuk melihat fenomena blue fire.

Ketahananan TWA Kawah Ijen dalam menerima kunjungan yang disesuaikan dengan daya dukung lingkungan akan menurun, ketika jumlah kunjungan mengalami peningkatan kunjungan seperti yang terjadi pada tahun 2014 dengan jumlah wisatawan asing sebesar 15.905 dan 74.163 wisatawan domestik serta jumlah kunjungan tahun 2016 sebanyak 29.256 wisatawan asing dan 164.947 wisatawan domestik. Rata rata kunjungan wisatawan per hari pada tahun $2016 \pm 532$ wisatawan, angka tersebut tentunya sangat melebihi angka DDL yang telah ditetapkan, dan tidak termasuk jumlah penambang yang melakukan kegiatan penambangan setiap harinya.

Perubahan fungsi blok juga terjadi di area pemanfaatan terbatas yang kini direncanakan sebagai bentuk memecah kunjungan wisatawan penambahan sejumlah sarana dan prasarana pariwisata serta atraksi wisata, di antaranya area Kali Pahit, puncak sunrise Pondok Bunder yang kini terdapat warung semi permanen sebagai peluang usaha ketika pariwisata meningkat. Kegiatan yang sering dilakukan pada blok pemanfaatan terbatas diantaranya swafoto dan ketertarikan wisatawan terhadap tambang belerang dengan resiko kecelakaan yang tinggi dikarenakan jalur pendakian yang curam. Hal demikian menyebabkan ketahananan area akan menurun dan proses recovery akan lebih panjang, serta struktur jalur pendakian yang rawan longsoran akan mengakibatkan perubahan jalur.
Kegiatan dalam menjaga ketahananan lingkungan dalam menghadapi perubahan fungsi lahan dan guna lahan sangat diperlukan, beberapa program pengelolaan dilaksanakan demi menjaga ketahananan ekosistem, penutupan TWA Kawah Ijen selama satu hari penuh setiap awal bulan di hari Jum'at minggu pertama, penanaman bibit - bibit baru di beberapa titik konservasi dan pelarangan perburuan serta penebangan atau pengambilan flora endemik. Diberlakukan larangan pada setiap kegiatan dengan intensitas suara tinggi dan beberapa perayaan yang menggunakan alat peledak atau kembang api, himbauan untuk tidak menyalakan api unggun dikarenakan sisa pembakaran dikhawatirkan dapat menimbulkan kebakaran hutan terutama saat musim kering.

\subsection{Dampak Lingkungan Sosial Ekonomi}

Dampak sosial ekonomi yang ditimbulkan oleh perkembangan pariwisata TWA Kawah Ijen terbagi atas berbagai kelompok, peningkatan jumlah pendapatan di TWA Kawah Ijen dari retribusi penjualan tiket masuk kawasan dan retribusi lainnya setiap tahunnya mengalami peningkatan, pertumbuhan jumlah wisatawan dianggap sebagai peluang dalam pendapatan dan penerimaan devisa negara.

Penerimaan PNBP jika biaya retribusi masuk dan lainnya sebesar Rp 5.000 pada hari biasa dan Rp 7.500 pada hari libur untuk wisatawan domestik dan Rp 100.000 pada hari biasa, Rp 150.000 pada hari libur untuk wisatawan asing. Rata rata pendapatan PNBP TWA Kawah Ijen jika dihitung dengan biaya retribusi pada hari biasa selama setahun pada tahun 2018 
dengan jumlah kunjungan wisatawan asing 25.810 dan wisatawan domestik $150.285 \pm \operatorname{Rp} 2.581 .000 .000$ dari pendapatan wisatawan asing dan $\mathrm{Rp}$ 751.425.000. Jika kunjungan pada musim libur lebih tinggi, maka pendapatan PNBP jauh melampaui angka tersebut. Dampak kunjungan wisatawan juga memberikan peningkatan pendapatan masyarakat, terutama bagi penyedia usaha jasa wisata di TWA Kawah Ijen, dari 100 responden pemilik jasa usaha wisata di TWA Kawah Ijen sebesar $53 \%$ memberikan pendapat bahwa pariwisata berdampak baik terhadap pendapatan masyarakat lokal dan $42 \%$ berpendapat bahwa pariwisata berdampak sangat baik terhadap peningkatan pendapatan mereka, sebagaimana yang tersaji pada tabel 4.3.

\section{Tabel 4.3}

\section{Persepsi Masyarakat Terhadap Dampak Ekonomi Pariwisata}

Dampak Terhadap Pendapatan Masyarakat

\begin{tabular}{cccccc}
\hline & $\begin{array}{c}\text { Frequenc } \\
y\end{array}$ & Percent & $\begin{array}{c}\text { Valid } \\
\text { Percent }\end{array}$ & $\begin{array}{c}\text { Cumulative } \\
\text { Percent }\end{array}$ \\
\hline Valid & 1 & 1 & 1,0 & 1,0 & 1,0 \\
& 2 & 2,0 & 2,0 & 3,0 \\
3 & 2 & 2,0 & 2,0 & 5,0 \\
4 & 53 & 53,0 & 53,0 & 58,0 \\
5 & 42 & 42,0 & 42,0 & 100,0 \\
& Total & 100 & 100,0 & 100,0 & \\
\hline
\end{tabular}

Sumber: Data Sekunder diolah, 2020

Dampak pariwisata tentu juga memengaruhi harga - harga keperluan sehari - hari, kekurangan pasokan dan tingginya biaya distribusi menuju daerah pariwisata yang merupakan lokasi dengan sarana transportasi yang terbatas, menjadikan sejumlah bahan keperluan sehari - hari di TWA Kawah Ijen lebih tinggi dari pada daerah sekitar.

Masyarakat berpendapat bahwa dengan adanya pariwisata harga kebutuhan hidup mengalami peningkatan, perkembangan pariwisata menimbulkan dampak buruk, kurangnya pasokan barang dan tingkat persaingan dalam mendapatkannya antara masyarakat dan wisatawan mengakibatkan kelangkaan beberapa barang kebutuhan sehingga memengaruhi harga.

Kemunculan penduduk baru dan pemilik modal baru akan mendominasi pembangunan dan perkembangan daerah, manfaat peningkatan pendapatan pariwisata akan lebih banyak dirasakan bagi mereka yang memiliki kontrol kepemilikan usaha wisata.

Perubahan gaya hidup masyarakat yang mengikuti gaya budaya wisatawan juga menjadi penyebab meningkatnya kebutuhan sehari - hari. Dampak sosial lainnya yakni perubahan pada pola modifikasi, konsumsi, infrastruktur dan komoditas. Kebutuhan untuk diakui dengan apa yang dapat masyarakat beli serta gunakan hingga kini masih menjadi gaya hidup masyarakat. Keberadaan pariwisata juga menimbulkan sifat materialisme, segala sesuatu akan baik dan dapat dilakukan jika dinilai dengan materi atau uang.

Pariwisata juga sebagai faktor luar yang memengaruhi perubahan di dalam masyarakat. Sadar pariwisata merupakan kunci utama dalam setiap kegiatan pariwisata terutama bagi penerima yaitu masyarakat lokal. Seringkali pariwisata juga berdampak pada beberapa aspek sosial masyarakat, termasuk aspek demografi yang berkaitan dengan peningkatan jumlah penduduk.

Perubahan demografi menurut pendapat dari responden, kecenderungan tingginya pendatang baru seringkali menimbulkan konflik didalam persaingan usaha wisata. Beberapa kelompok usaha merasa bahwa pendatang baru akan 
menjadikan ancaman dalam mendapatkan manfaat pariwisata.

Tabel 4.4

Persepsi Masyarakat mengenai Dampak Pariwisata terhadap Pendatang

\begin{tabular}{llrrrr}
\hline & & $\begin{array}{c}\text { Frequen } \\
\text { cy }\end{array}$ & $\begin{array}{c}\text { Percen } \\
t\end{array}$ & $\begin{array}{c}\text { Valid } \\
\text { Percent }\end{array}$ & $\begin{array}{c}\text { Cumulativ } \\
\text { e Percent }\end{array}$ \\
\hline Vali & 2 & 58 & 58,0 & 58,0 & 58,0 \\
$d$ & 3 & 14 & 14,0 & 14,0 & 72,0 \\
& 4 & 25 & 25,0 & 25,0 & 97,0 \\
& 5 & 3 & 3,0 & 3,0 & 100,0 \\
& Tota & 100 & 100,0 & 100,0 & \\
\hline & 1 & & & & \\
\hline
\end{tabular}

Sumber: Data Primer diolah, 2020

Tabel 4.4 menjelaskan mengenai dampak pariwisata terhadap pendatang baru dari 100 responden $58 \%$ merasa pariwisata memberikan dampak buruk terhadap jumlah pendatang di kawasan wisata. Persaingan dalam kegiatan ekonomi juga berdampak terhadap perubahan pekerjaan dan distribusi pekerjaan.

\section{Simpulan dan Saran}

\subsection{Simpulan}

Perkembangan pariwisata TWA Kawah Ijen saat ini berada dalam tahap development, pihak swasta mulai masuk dan ikut andil dalam perkembangan pariwisata. Ketidak sesuaian penggunaan lahan kerap terjadi dalam perkembangan TWA Kawah Ijen, perubahan alih fungsi lahan dalam pembangunan sarana prasarana wisata menjadi catatan penting dalam pengembangan ekowisata. Dampak lain dari pariwisata pada aspek sosial ekonomi baik positif dan negatif terjadi berimbang, pada peningkatan pendapatan masyarakat maupun kesenjangan dan kecemburuan dalam menghadapi pendatang baru dilingkungan masyarakat, terutama bagi mereka yang juga sebagai pemilik usaha wisata di TWA Kawah Ijen.
Sehingga persepsi yang terjadi di dalam masyarakat pelaku usaha wisata dapat berbeda, terutama jika menyangkut aspek pendapatan dan ekonomi.

\subsection{Saran \\ Bagi pembuat dan pelaksana} kebijakan diharapkan dalam perencanaan dan evaluasi perkembangan TWA Kawah Ijen memperhatikan daya dukung lingkungan serta desa penyangga yang masyarakat lokal ikut terlibat dalam kegiatan pariwisata TWA Kawah Ijen. Koordinasi antar stakeholder penting dilakukan untuk meminimalisir dampak negatif perkembangan pariwisata. Penelitian lanjutan diperlukan terutama mengenai konflik pengelolaan maupun antar unit usaha jasa wisata yang ada di TWA Kawah Ijen.

\section{DAFTAR PUSTAKA}

Butler, Richard W. 2006. The Tourism Area Life Cycle, Vol. 1 Applications and Modifications. Channel View Publications, Bristol.

Chapman, A., \& Light, D. 2016. Exploring the tourist destination as a mosaic: The alternative life cycles of the seaside amusement arcade sector in Britain. Bournemouth: Bournemouth University, Tourism Management, 52, 254-263.

Kotler, Philip. 2002. A Framework for Marketing Management. New Jersey: A Pearson Education Company, Upper Saddle River.

Kusumastuti, A. H., \& Pamungkas, A. 2018. Identifikasi Potensi dan Permasalahan Daya Dukung Lingkungan berdasarkan Aspek Daya Dukung Fisik, Daya Dukung Ekologis, dan Daya Dukung Sosial pada Pantai Baron, Kabupaten Gunungkidul, Yogyakarta. Jurnal Teknik ITS, 7(1), 55-59. 
Pemerintah Indonesia. UU Nomor 5 Tahun 1990 Tentang Konservasi Sumber Daya Alam Hayati dan Ekosistem

Pemerintah Indonesia. Keputusan Menteri Pertanian No. 1017/Kpts-II/Um/12/1981 Tentang Penetapan CA Kawah Ijen Merapi Ungup - Ungup dan TWA Kawah Ijen

Pemerintah Indonesia. Peraturan Menteri Kehutanan Nomor P.48/Menhut-Ii/2010 Tentang Pengusahaan Pariwisata Alam Di Suaka Margasatwa, Taman Nasional, Taman Hutan Raya Dan Taman Wisata Alam

Pemerintah Indonesia. SK Direktur Jenderal Perlindungan Hutan dan Pelestarian Alam no: 51/Kpts/Dj-VI/87 tanggal 12 Desember 1987 Tentang penunjukan mintakat pada Taman Nasional (TN), TWA atau CA Kawah Ijen

Pemerintah Indonesia. SK Direktur Jenderal PHKA nomor: SK.131/IV-KKBHL/2013. Tentang Penataan blok TWA Kawah Ijen.

Pitana, I Gde dan I Ketut Surya Diarta. 2009. Pengantar Ilmu Pariwisata. Yogyakarta: Penerbit Andi.

Suryawardani, I. G. A. O. 2017. A Structural Model of Foreign Tourists. Loyalty in Nature- based Tourism in Bali, International Journal of Applied Business and Economic Research, 15(9), 195-215.

Widowati, S., \& Nadra, N. M. 2017. Evaluasi Penerapan Prinsip-Prinsip dan Kriteria Ekowisata Di Kawasan TWA Kawah Ijen Banyuwangi. Soshum: Jurnal Sosial dan Humaniora, 3(3)

Wijaya, I. N., \& Kanca, I. N. 2017. Dampak Pembangunan Pariwisata dalam Perkembangan Pariwisata Provinsi Bali. Soshum: Jurnal Sosial dan Humaniora, 3(2 Juli).
Leily Suci Rahmatin, lahir di Bondowoso, 7 Mei 1994. Menyelesaikan pendidikan Sarjana S1 Pariwisata Program Studi Destinasi Pariwisata di Fakultas Pariwisata Universitas Udayana tahun 2016. Menyelesaikan Program Magister Pariwisata tahun 2019. Pengalaman yang dimiliki sebagai pengajar tidak tetap di SMK Negeri 2 Bondowoso sejak tahun 2016 - 2017, pengajar tidak tetap di Akpar Denpasar tahun 2017 - 2018. Desen LB di Politeknik Banyuwangi 2020 - 2021 sejak September 2020 menjadi Dosen Tetap di UPN Veteran Jawa Timur.

\section{PROFIL PENULIS}

